\title{
IAMJ
}

INTERNATIONAL AYURVEDIC MEDICAL JOURNAL

\section{ROLE OF MAHAT PANCHA GAVYA GHRITA IN DEPRESSION - A CONCEPTUAL STUDY}

\section{Durga. E}

Associate Professor, Ahalia Ayurveda Medical College, Kozhippara. P.O, Palakkad, PIN-678557, Kerala, India

Email:drdurgae@gmail.com

\section{https://doi.org/10.46607/iamj0807132020}

(Published online: July 2020)

Open Access

(C) International Ayurvedic Medical Journal, India 2020

Article Received: 06/06/2020 - Peer Reviewed: 25/06/2020 - Accepted for Publication: 01/07/2020

\section{Check for updates}

\begin{abstract}
One of the most ancient systems of medicine-Ayurveda, developed thousands of years ago, even today continues to stun the scientific faculties all over the world by its highly evolved concepts. Psychiatry is the branch dealing with the disorders of mind and its management. Among the eight branches in Ayurveda, 'Bhutavidya' is the Ayurvedic psychiatric branch. Ayurveda adopts a comprehensive psychosomatic approach, for the management of the diseases. Ayurveda can be adopted as an effective mode of intervention in depression.
\end{abstract}

Keywords: Depression, Kaphajonmada, Mahat Pancha Gavya Ghrita

\section{INTRODUCTION}

The emotions of sadness, unhappiness or disappointment are a part of human existence and are experienced by everyone almost on a daily basis. Such emotions may be associated with failure in academics, loss in a financial investment, break-up of a love affair, or with the death of a loved one. However, after feeling sadness for a few days during which time there can be changes in the sleep pattern and appetite, disinterest in daily chores etc., the person usually returns to normal life within a reasonable period. On the other hand in some cases this state of sadness or unhappiness continue to accumulate to such a degree and for such a length of time that it far outweighs the significance of the precipitating factor. The sufferer continues to be in a prolonged state of sadness and becomes withdrawn from his or her personal, social and occupational ac- 
tivities. In such situations, a diagnosis of the disease condition of depression should be considered. It is a mental illness that disturbs the person both mentally and physically and it can also disrupt the entire family life. World Health Report 2001 has identified depression as the $4^{\text {th }}$ cause of Disability Adjusted Life Years (DALY's) in all ages, and the $2^{\text {nd }}$ cause in the age group of 15-44 years. Depression is also the $1^{\text {st }}$ cause of YLD (Years of Life Lived with Disability) in all ages. The World Health Report 2001 estimates that there are 121 million people worldwide suffering from depression $^{[1]}$

\section{ICD 10 Diagnostic Criteria for Depression ${ }^{[2]}$}

The most Typical Symptoms are

1. Depressed mood

2. Loss of interest and enjoyment

3. Reduced energy leading to increased fatigability and diminished activity

\section{Other Common Symptoms:}

1. Reduced concentration and attention

2. Reduced self- esteem and self confidence

3. Ideas of guilt and unworthiness (even in mild type of episode)

4. Bleak and pessimistic views of future

5. Ideas or acts of self -harm or suicide

6. Disturbed sleep

7. Diminished appetite

\section{Unmada}

Indian scriptures and Ayurvedic classics are a vast source for the development of Ayurvedic psychiatry. Bhuta vidya is the branch of Ayurveda that deals with abnormal behaviour of a person. Any condition that perverts mind, intellect, consciousness, memory, desire, manner, behaviour, and conduct can be called as Unmada ${ }^{[3]}$. There are generally 5 types of Unmada ${ }^{[4]}$, i.e. Vatika, Paittika, Kaphaja, Sannipatika and Agantuja. Among those when we consider the symptoms of Kaphajonmada and symptoms of depressive disorders, we can find that most of the symptoms of both are similar.
Correlation of Kaphajonmada Symptoms with depression Table 1:

\begin{tabular}{|l|l|}
\hline Kaphajonmada & Depression \\
\hline Arochaka & Tastelessness \\
\hline Alpaceshta & Reduced activities \\
\hline Alpavak & Reduced talk \\
\hline Alpahara & Taking less food \\
\hline Sadana & Increased fatigue \\
\hline Rahapriti & Likes solitude \\
\hline Saucavidwesha & Aversion to cleanliness \\
\hline Baibhatsyam & Disgusting look \\
\hline Atinidra & Increased sleep \\
\hline Sthanamekadese & $\begin{array}{l}\text { Remaining in one place with little } \\
\text { movements }\end{array}$ \\
\hline Agnimandya & Indigestion \\
\hline Alpamati & Less attention and concentration \\
\hline Tushni bhava & Indifference \\
\hline Alpaschankramana & Less movements \\
\hline Anannabhilasha & Reluctancy to take food \\
\hline Svapnanityata & Sleeping most of the time \\
\hline
\end{tabular}

These are the symptoms which show direct relationship between Kaphajonmada and depressive disor$\operatorname{ders}^{[5]}$

\section{Importance of Sneha in Unmada Chikitsa}

Sneha constitutes an important part of Shamana Chikitsa and plays a significant role in the proper nourishment of the body. Therefore, from ancient time, people preferred to consume milk and Ghrita in their daily routine life. In Ayurveda, Ghrita stands first and the best in Sneha Varga Dravyas. It is very popular as diet and medicine used for Rasayana, Agnidipana, Medhya, Chakshushya etc. General properties of Sneha include Guru (heavy), Sita (cold), Sara (fluid), Snigdha (unctuous), Manda (sluggish), Sukshma (subtle) Mridu (soft), Drava (liquid) ${ }^{[6] . ~ G h r i t a ~ i s ~ i d e a l ~ f o r ~ i m p r o v i n g ~ i n t e l l i g e n c e, ~}$ memory, digestion, long life, sexual vigour and eyesight. It is good for children, the aged and those who desire more children. It is good for those suffering from emaciation as a result of injury to chest, injury from weapons and fire, disorders of Vata and Pitta origin, poison, insanity, and fevers. It is best among fatty materials. Best for retaining youth; capable of giving a thousand good effects by a thousand kinds of 
processing ${ }^{[7]}$. In Bhava Prakasha, it has been mentioned that Ghrita is Rasayana, tasty, conducive for eye, stimulant for digestion, supports complexion, enhances memory and stamina, protects the body from various diseases and promotes longevity. Apart from the similar properties, mentioned in other classics, the special indications include Unmada, Apasmara, Ma$d a$, Murcha and other neuropsychological disorders. ${ }^{[8]}$ Biochemical findings suggest that

- Ghrita is having the capacity to cross the bloodbrain barrier.

- Lipophilic action of Ghrita facilitates transportation to a target organ (brain) and final delivery inside the cell, because cell membrane also contains lipids.

- It contains anti-oxidants, beta-carotene and vitamin E, which scavenges free radicals.

- It contains an essential fatty acid, linolenic acid, which promotes proper growth of human body.

- It has been found through research that when herbs are mixed with Ghrita, their activity and utility is potentiated many a times. ${ }^{[9]}$

Ghrita in general and Goghrita in particular, is one of the easily digestible and absorbable food that provides essential nutrients and critical anti-oxidants to the human body for its protection and growth. It enhances the quality of its formulations several fold promoting the delivery to the target organs and producing the required results. Hence the Ghrita has been selected as a formulation for the effective intervention.

\section{Mahat Pancha Gavya Ghrita}

Mahat Pancha Gavyaghrita is one of the important formulations widely used in Manasika Roga Chikitsa. It is a time tested and traditionally practiced drug. Even though it is mentioned in Apasmara Prathishedha by all Acharyas, clinically it shows good results in Unmada also. As per Charak Acarya, therapeutic measures which are described in Apasma$r a$ should also be applied to a patient suffering from Unmada, because both Apasmara and Unmada share the same Hetu and Dushya ${ }^{[10]}$.

Preparation of Mahat Pancha Gavya Ghrita ${ }^{[1]} \mathrm{Ma}$ hat Pancha Gavya Ghrita is prepared according to the classical method of Ghrita preparation.Two Pala each of the two Panchamulas, Triphala, the two Nisa, bark of Kutaja, Saptaparna, Apamarga, Nilini, Katurohini, Samyaka, Puskarajata, root of Phalgu and Duralabha - are boiled in one drona of water and decoction reduced to one fourth. To this are added the paste of one Aksha each of Bharngi, Pata, Adhaki, Kumbha, Nikumbha, Vyosha, Rohisa, Murva, Bhuunimba,Putika, Sreyasi, the two Sariba, Madayanti, Agni, and Nicula; one Prastha of Ghrita, and liquids mentioned earlier (juice of fresh dung, milk, curd, and urine of the cow) and medicated Ghrita prepared. Known as Mahat Pancha Gavya Ghrita, it is best to cure Jwara, Apasmara, Jatara, Bhagandara, Sopha, Arsa, Kamila, Pandu, Gulma, Kasa and diseases caused by Grahas $^{[12]}$.

\section{DISCUSSION}

As most of the ingredients of this Yoga have TiktaKatu rasa (36.7\% and $24.4 \%$ respectively), RukshaTeekshnagunas (26.2\% and $15.9 \%$ respectively), Ushna virya (70.2\%) and Katu vipaka (63.8\%), it is a Kapha hara drug. While assessing Doshaghnata, it is found that Mahat Pancha Gavya Ghrita is Kapha Vatahara predominantly ${ }^{[13]}$. Kaphajonmada is a disease having Kapha Vata predominance (40.4\%). So, it is apt to give Mahat Pancha Gavya Ghrita, which is a Kapha Vatahara drug in kaphajonmada. As this is a Ghrita preparation it is Agnidipana, Medhya,Balakara and Ojovardhaka. Moreover, in Ashtanga Samgraha, Pancha Gavya Ghrita is specially indicated for Kaphajonmada. In Pancha Gavya Ghrita, only animal products are used. But in Mahat Pancha Gavya Ghri$t a$, there are both animal products and herbal products having Kapha Vata hara property. So Mahat Pancha Gavya Ghrita will be more beneficial than Pancha Gavya Ghrita especially in the management of Kaphajonmada. Mahat Pancha Gavya Ghrita is described as Amritopamam, Alakshmi Grahaghnam and rakshoghnam in Charakasamhita. It contains drugs having psychotropic effect like Vacha.In Unmada Prakarana, acharyas mentioned a lot of Ghrita preparations than any other preparations. Vagbhatacarya explained that Ghrita is good for Dhee, Smriti, Medha and Agni. As the Ghrita possess Sukshma property, it 
can spread all over the body very easily. The Ghrita is Vata Pittahara and the drugs are having Kaphahara property. So, the medicine possesses Tridoshahara property. Majority of the drugs in Mahat Pancha Gavya Ghrita having Sodhana property. For eg: for Vamana, Kutacha and nichula; for Virechana, Katurohini,Aragwadha, Danti and Nilini; for Sirovirechana, Haridra, Apamarga,Pippali are used. Thus, the drug can be called a Sodhana Dravya given in Samana Matra. Hence it fulfills both the objectives of Sodhana and Samana. This brings about Srotosodhana. As Unmada is an Avarana Janya Vyadhi it is quite apt to give a Sroto Sodhaka drug like Mahat Pancha Gavya Ghrita. Ghrita itself the best Rasayana, forms the base.

\section{CONCLUSION}

Depression is a significant public health problem because of its high prevalence, the sufferings, and sometimes death, that it causes. Suicide is a major risk during the course of depression. Depression can be correlated with Kaphajonmada in Ayurveda. Mahat Pancha Gavya Ghrita has significant effect in Kaphajonmada.

\section{REFERENCES}

1. Niraj Ahuja, A short textbook of psychiatry, Jaypeebrothers medical publishers, $6^{\text {th }}$ edition (2006) New Delhi

2. American Psychiatric Association, 1994, International Classification of Diseases-

3. Agnivesha, Charakasamhita (translated by RK Sharma and Bhagvan Dash), Choukamba Sanskrit Series Office, Varanasi, vol.2, chapter $7 / 5$

4. Agnivesha, Charakasamhita (translated by RK Sharma and Bhagvan Dash), Choukamba Sanskrit Series Office, Varanasi, vol.3, 9/8

5. Shaik Anwar, A study on Kaphajonmada in relation with depressive disorders, Thesis submitted to VPSV Ayurveda College Kottakkal, 2004

6. K.R Srikantha Murthy, Ashtanga Hridaya $1^{\text {st }}$ edition (2018) Chowkhamba Krishnadas academy Varanasi, $16 / 1$

7. K.R Srikantha Murthy, Ashtanga Hridaya $1^{\text {st }}$ edition (2018) Chowkhamba Krishnadas academy Varanasi, 5/37-39
8. Bhavamisra, Bhavaprakasha, Chaukamba Sanskrit Pratishtana, Varanasi. B.P. Ghritavarga 1-3

9. Anumod Kakkassery, An open clinical trial on Panchagavyaghrita in Schizophrenia, Thesis submitted to VPSV Ayurveda college Kottakkal,2010

10. Agnivesha, Charakasamhita (translated by RK Sharma and Bhagvan Dash), Choukamba Sanskrit Series Office, Varanasi, vol.3,9/46

11. K.R Srikantha Murthy, Ashtanga Hridaya $3^{\text {rd }}$ edition (2018) Chowkhamba Krishnadas academy Varanasi, 7/19-21

12. K.R Srikantha Murthy, Ashtanga Hridaya $3^{\text {rd }}$ edition (2018) Chowkhamba Krishnadas academy Varanasi, $7 / 22-23$

13. Durga. E, An open trial on the effect of Mahatpancagavyaghrita in kaphajonmada with special reference to moderate depressive disorder. Thesis submitted to VPSV Ayurveda college Kottakkal,2011

\section{Source of Support: Nil}

\section{Conflict of Interest: None Declared}

How to cite this URL: Durga. E: Role Of Mahat Pancha Gavya Ghrita In Depression - A Conceptual Study. International Ayurvedic Medical Journal \{online\} 2020 \{cited July, 2020\} Available from: http://www.iamj.in/posts/images/upload/3903 3906.pdf 